\title{
REIMBURSEMENT OF PUBLIC INTERVENORS
}

In Office of Communication of the United Church of Chirist $v$. $F C C{ }^{1}$ the Court of Appeals for the District of Columbia Circuit held that the FCC must permit voluntary reimbursement of the legitimate and prudent expenses of bona fide public-interest groups who withdraw petitions to deny renewal of a broadcast license whenever such withdrawal serves the public interest. The controversy arose in 1969, when the Texarkana Junior Chamber of Commerce and eleven other local groups, assisted by the Church of Christ, filed a petition under section 309(d) of the Communications Act $^{2}$ opposing the renewal of television station KTAL's broadcast license. $^{3}$ Subsequent to the filing of this petition, the local groups and KTAL management reached an agreement whereby the local groups would withdraw their petition to deny rehicensing and, in return, the station would inake certain specified changes im its operations and policies. ${ }^{4}$ The station also agreed that if the Commission granted renewal of its license pursuant to this agreement, the station would, subject to further Commission approval, voluntarily reimburse the petitioners for the expenses incurred in prosecuting the petition to deny. Relying upon the parties' agreement, the FCC renewed KTAL's license. Thereafter, the Office of Communication of the United Church of Christ, which had provided legal advice and other support to the local groups, filed a request with the FCC for approval of the parties' supplementary reimbursement agreement.

1. 465 F.2d 519 (D.C. Cir. 1972).

2. 47 U.S.C. $\$ 309$ (d) (1970).

3. The local groups charged, inter alia, that KTAL-TV had failed to serve the needs of the coinmunity, particularly those of the black viewing audience; that KTAL had not contacted any black leaders in its survey of community needs; and that the station neither presented public announcements for black groups nor invited minority groups to discuss issues on its public affairs shows. For a full statement of petitioner's grievances, see KCMC, Inc., 19 F.C.C.2d 109, 113, 16 P \& F RADIO REG. 2D 1067, 1072 (1969).

4. KTAL promised, inter alia, (1) to employ a minimum of two full-time black reporters; (2) to maintain a full-time operator to answer a toll-free telephone; (3) to assign a color camera to its Texarkana studio; and (4) to consult monthly with all community leaders. For a complete statement of the terms of the agreement, see id. at 120-22, 16 P \& F RADro REG. 2D at 1079-81. 
The Commission, however, refused to approve this aspect of the compromise and decided that "in no petition to deny situation, whatever the nature of the petitioner, will we permit payment of expenses . . . ."5 On appeal by the Office of Communication, the Court of Appeals for the District of Columbia Circuit rejected the Commission's absolute bar and remanded for reconsideration of whether the expenses were "legitimate and prudent."

The Communications Act of $1934^{7}$ created the Federal Coinmumications Commission to regulate the use of the airwaves for the public benefit. The Act established, inter alia, a system for the licensing of radio and television stations. The FCC, im accordance with its statutory mandate, may grant an imitial or renewal license only if "the public interest, convenience, and necessity will be served by the granting of such application ....." These licenses are granted for a maximum of three years ${ }^{9}$ and may be renewed by application to and upon approval by the Commission. ${ }^{10}$ Pursuant to section 309(d) of the Act, however, "any party im interest may file with the Commission a petition to deny any application . . .."11 Thereafter, if the Commission determines that a "substantial and material question of fact is presented" or that it is presently unable to make the finding that granting the application would serve the public interest, a hearing on the matter is scheduled. ${ }^{12}$ Section 311(c), the only provision of the Act which explicitly deals with reimburseinent, covers the specialized case of inultiple applications for a single new broadcast facility construction permit. This section, enacted as an amendment to the Communications Act, establishes a minimal procedure that the Commission must follow before it can approve the withdrawal and reimbursement of any applicant. ${ }^{13}$ While the Act does not expressly deal with other specific situations in which reimbursement agreements may arise-imcluding the withdrawal and voluntary reimbursement of petitioners to deny-the

5. KCMC, Inc., 25 F.C.C. $2 d$ 603, 605, 20 P \& F RADIO REG. 2D 267, 269 (1970).

6. 465 F.2d at 528 . See note 41 infra.

7. 47 U.S.C. $\$ \$ 151-609$ (1970) (originally enacted as Act of June 19, 1934, ch. 652,48 Stat. 1064).

8. $1 d$. $\$ 309(\mathrm{a})$.

9. $1 d$. $\S 307(\mathrm{~d})$.

10. $I d$.

11. Id. $\S 309$ (d)(1).

12. Id. \& 309(e). 893).

13. Id. \& 311 (originally enacted as Act of Sept. 13, 1960, \& 5, 74 Stat. 889, 
FCC is vested with sufficiently broad discretionary powers which encompass such problems. ${ }^{14}$ Exercising its discretionary powers to deal with withdrawal and reimbursement agreements, ${ }^{15}$ the Commission had continued to consider reimbursement agreements not explicitly imcluded within the statutory language subsequent to the enactinent of section 311(c). ${ }^{16}$ The Commission concluded that section 311(c) sought only to eliminate specific abuses that had arisen in the context of multiple original license applicants and thus did not mandate an absolute bar against other reimbursement situations. ${ }^{17}$ In these non-section 311(c) cases, the Commission had held that the "spirit" of section 311(c) applied and had occasionally approved withdrawal and reimbursement agreements which terminated litigation if it found the public interest was thus served. ${ }^{18}$

Withdrawal and reimbursement agreements ordinarily fall into two categories. ${ }^{19}$ The first and most common category-inultiple applicants for a new construction permit-is resolved by the specific

14. The Commission may "perform any and all acts, make such rules and regulations . . . not inconsistent with this chapter as may be necessary in the execution of its function." Id. $\$ 154(\mathrm{i})$. The Commission also is empowered to prescribe "such ... restrictions and conditions ... as may be necessary ...." Id. $\$ 303(\mathrm{r})$.

15. The Commission has consistently utilized the public interest standard to determine whether a reimbursement agreement should be approved. As an illustration of this public interest standard, mandated by $\$ 309$ (a) of the Communications Act, the Commission recently indicated that "in deciding whether to approve a withdrawal [-reimbursement] agreement between competing applicants, benefits and detriments to the public interest must be weighed." WFMY Television Corp., 33 F.C.C.2d 857, 23 P \& F Radio Reg. 2D 1032, 1033 (1972). Accord, Seven League Prod., Inc., 7 F.C.C.2d 513, 514, 9 P \& F RAdio REG. 2D 773, 775 (1967); National Broadcasting Co., 25 P \& F RADio REg. 67, 72 (1963).

16. See, e.g., Woma Typa Broadcasting Co., 1 P \& F Radio REg. 2D 323 (1963); Capital Broadcasting Corp., 3 F.C.C.2d 285, 7 P \& F RAdro Reg. 2D 226 (Rev. Bd. 1966).

17. "The inapplicability of section $311(\mathrm{c})$ does not mean ... [that] the Commission has no authority to pass upon the joint petition in this case." National Broadcasting Co., 25 P \& F RAdio REG. 67, 71 (1963). See note 26 infra.

18. National Broadcasting Co., 25 P \& F Radio Reg. 67, 71 (1963); see Office of Communication of the United Church of Christ v. FCC, 465 F.2d 519, 525-27 (D.C. Cir. 1972). See notes 28-30 infra and accompanying text.

19. A third type of case-reimbursement of public advisory gfoups to broadcast stations-has recently come before the FCC. The Commission refused to allow the station to reimburse the advisory group for sunis expended in fulfilling its duties. However, the Commission also decided that the problen was "troublesome" and ordered a Notice of Inquiry to investigate this situation. Strauss Broadcasting Co., 31 F.C.C.2d 550, 22 P \& F RADIO REg. 2D 806 (1971). This investigation will consider the feasibility of a rule to deal with reimbursement situations, involving petitioners to deny and local advisory groups. 37 Fed. Reg. 11592 (1972). 
language of section 311(c). The FCC has often approved withdrawal and reimbursement agreements of this category, ${ }^{20}$ determining that the obvious public benefits (such as the early institution or restoration of broadcast service $\mathrm{m}$ an area without the delay of a long and expensive comparative hearing) outweighs the public detriment of losing the choice between two competing applicants. ${ }^{21}$ The Commission has refused, lowever, to approve such settlements if: unresolved questions concerning (1) the character qualifications of either applicant, ${ }^{22}$ (2) misrepresentations or other abuses of the Commission's processes, ${ }^{23}$ (3) financial or legal qualifications, ${ }^{24}$ or (4) the good faith filing of an application ${ }^{25}$ remain outstanding. The second category of withdrawal and reimbursement agreement concerns an applicant for a construction permit and a license renewal applicant. Although the Communications Act does not deal explicitly with reimbursement agreenents of this category, the FCC has found authority to approve or disapprove such agreements under its public-interest standard. ${ }^{26}$ But the Commission has also

20. .In all reimbursement agreement cases, the withdrawal of an application pursuant to the reimbursement agreement can be "consistent with the public interest, convenience, or necessity only if the amout or value of such payment, as determined by the Commission,... [has] been legitimately and prudently expended. ..." Grand Broadcasting Co., 5 P \& F Radio REg. 2D 527, 529 (1965). See National Broadcasting Co., 24 F.C.C.2d 218, 219-20, 19 P \& F RADIo REG. 2D 634, 635-36 (1970); National Broadcasting Co., 25 P \& F RAdio REG. 67, 72 (1963).

21. See, e.g., Alkima Broadcasting Co., 35 F.C.C. 635, 1 P \& F RAdIo REg. 2D 612 (1963); Broadcasting Service, Inc., 22 F.C.C.2d 1, 18 P \& F RADIO REG. 2D 673 (Rev. Bd. 1970); American Colonial Broadcasting Corp., 8 P \& F RAdIO REG. 2D 657 (Rev. Bd. 1966); Tri-Cities Broadcasting Co., 6 P \& F RADIo REg. 2D 1 (Rev. Bd. 1965); Rockland Broadcasting Co., 3 P \& F RADIO REg. 2D 553 (Rev. Bd. 1964).

22. See, e.g., People's Broadcasting Co., 8 F.C.C.2d 749, 10 P \& F RAdio Reg. 2D 592 (1967); Publix Television Corp., 33 F.C.C. 98, 23 P \& F Radio Reg. 856 (1962); 1400 Corp., 11 F.C.C.2d 575, 12 P \& F RADIO REg. 2D 302 (Rev. Bd. 1968).

23. See, e.g., John A. Egle, 1 P \& F Rudio REg. 2D 344 (1963); Clay County Broadcasting Co., 7 P \& F RAdio REG. 2D 560 (Rev. Bd. 1966); Tri-Cities Broadcasting Co., 6 P \& F RAdio REg. 2D 1 (Rev. Bd. 1965).

24. See, e.g., Clay County Broadcasting Co., 7 P \& F RAdio Reg. 2D 560 (Rev. Bd. 1966); Tri-Cities Broadcasting Co., 6 P \& F RAdio Reg. 2D 1 (Rev. Bd. 1965).

25. See, e.g., Charles County Broadcasting Co., 3 P \& F Radio REg. 2D 915 (Rev. Bd. 1964).

26. In the landmark decision dealing with the question of the Commission's power to approve or disapprove non-section 311(c) reimbursement agreements, the Commission said:

In our view, $\S 311$ (c) did not bestow upon the Commission new authority to act in this field; it simply made clear that the Commission must pass on withdrawal agreements involving applications for construction permits, that it shall approve the agreements only if it determines it to be consistent with 
stressed, however, that "barring extraordinary circumstances, the challenger to a renewal [an applicant for a construction permit] cannot be reimbursed in any amount for his expenditures in preparing and prosecuting his application . . .."27 Since the benefit of immediate inauguration of a new broadcast service found in the first factual pattern is absent here, and since the present broadcast service continues while the choice between competing applicants is made, the Commission has ordinarily held that the deteriment of losing a choice between competing applicants outweighs the benefits to the public. ${ }^{28}$ Nevertheless, even in this factual matrix, the Commission has occasionally found those "extraordmary circumstances" and has approved withdrawal and reimburseinent agreements. For example, in Seven League Production, Inc., ${ }^{29}$ the Commission approved a withdrawal and reimbursement agreement even though the public would be deprived of a choice between competing applicants. ${ }^{30}$ The

\footnotetext{
the public interest and that the Commission may determine an agreement to be consistent with the public interest only if it does not entail payment in excess of "legitimate and prudent expenses." National Broadcasting Co., 25 P \& F RADIo REg. 67, 72 (1963).

The Commission had stated earlier that:

[t]he inapplicability, in terms, of 311 (c) does not mean . . . the Commission has no authority to pass upon the [reimbursement] agreement in this case. The Coinmission has, we think, full authority to do so under the public interest standard. Id. at 71 .
}

Prior to the enactment of section 311(c) the Commission had also approved reimbursement agreements. Premier Television, Inc., 17 F.C.C. 783 (1953). The majority of non-section 311 (c) reimbursement cases involve withdrawing applicants in challenger-renewal situations. See, e.g., Woma Typa Broadcasting Co., 1 P \& F Radio Reg. 2D 323 (1963); Capital Broadcasting Corp., 3 F.C.C.2d 285, 7 P \& F RADIo REg. 2D 226 (Rev. Bd. 1966).

There are a few situations in which the Colnmission has ruled on other types of reimbursement agreements. See, e.g., Strauss Broadcasting, Inc., 31 F.C.C.2d 550, 22 P \& F RADio REG. 2D 806 (1971) (the Commission ruled on a remibursement agreement between a station and a public advisory group); Telegrapli-Herald, Inc., 21 F.C.C.2d 974, 18 P \& F RADro REg. 2D 708 (Rev. Bd. 1970) (a reimbursement agreement which would expedite the inauguration of a new "DPLMR" service approved).

27. Policy Statement Concerning Comparative Hearing Involving Regular Renewal Applicants, 22 F.C.C.2d 424, 429 n.7, 18 P \& F RADIo REg. 2D 1901, 1908 n.7 (1970), invalidated on other grounds, Citizens Commumications Center v. FCC, 447 F.2d 1201 (D.C. Cir. 1971).

28. See, e.g., WFMY Television Corp., 33 F.C.C.2d 857, 23 P \& F RADio REg. 2D 1032 (1972); Cragin Broadcasting, 9 F.C.C.2d 687, 10 P \& F RADIo REg. 2D 1112 (1967); Woma Typa Broadcasting Co., 1 P \& F RADIo Reg. 2D 323 (1963); National Broadcasting Co., 25 P \& F RADIo Reg. 67 (1963); WMGS, Inc., 10 F.C.C. 2d 169, 11 P \& F RaDIo Reg. 2D 351 (Rev. Bd. 1967).

29. 7 F.C.C.2d 513, 9 P \& F Radio REg. 2D 773 (1967).

30. Id. Accord, Blue Island Community Broadcasting Co., 1 F.C.C.2d 629, 6 P \& F RADIO REg. 2D 136 (1965). 
countervailing public benefits were the elimination of all questions concerning the financial viability of the station and the fact that the new licensee would be comprised of distinguished local citizens. ${ }^{31}$

Although it properly applied a reduced standard of judicial review, ${ }^{32}$ the Court of Appeals for the District of Colunnbia Circuit nevertheless found it necessary to overrule the Commission's absolute bar against voluntary reimbursement of withdrawing petitioners to deny. ${ }^{33}$ The court concluded that the following policy is einbodied in the Communications Act: "reimbursement which facilitates withdrawal of competing or conflictimg petitions is definitely in the public interest when termination of the litigation serves an overriding public interest goal." ${ }^{34}$ The court also reflected upon the Commission's willinguess to consider reimbursement in non-petitioner to deny situations subsequent to the passage of section 311 (c) ${ }^{35}$ and formd it "imexplicable that the Commission should reject the 'spirit' of $\S 311$ (c) and its own line of cases in order to raise an absolute bar against reimbursement in all petitions to deny situations." 36 The court noted that the inajority of the Commission in erecting an absolute bar to voluntary reimbursement of withdrawing petitioners to deny, mentioned only two potential abuses: first, the terms of a settlement on the inerits might be influenced by the

31. Id. 7 F.C.C.2d 513, 514, 9 P \& F Radio REG. 2D 773, 775 (1967).

The Commission has also approved reimbursement when the withdrawing party filed his application in reliance upon a confusing FCC decision subsequently clarified to the detriment of the challenger. National Broadcasting Co., 24 F.C.C.2d 218, 219, 19 P \& F Radio REg. 2D 634, 635 (1970). Accord, Post-Newsweek Stations, Inc., 26 F.C.C.2d 982, 20 P \& F RADIo REg. 2D 730 (Rev. Bd. 1970).

However, the FCC has recently indicated that it will take a more restrictive attitude toward the granting of reimbursement, and disallowed a request on this ground. WFMY Television Corp., 33 F.C.C.2d 857, 23 P \& F RAdio REg. 2D 1032 (1972). On this question the Commission stated:

We did waive the policy [of denying reimbursement in a case involving a construction permit applicant and license renewal applicant] in the unusual circumstances of the 1970 National Broadcasting Co., and Post-Newsweek cases. We do not now hold that this area is settled in all respects. .... It may be a considerable period of time before all significant aspects of pohicy in the field are settled. Id. at 860, 23 P \& F RADIO REG. 2D at 1035 .

32. "The Commission's construction of its own statutory mandate 'should be followed unless there are compelling indications that it is wrong.' " Office of Communication of the United Church of Christ v. FCC, 465 F.2d 519, 524 (D.C. Cir. 1972).

33. Id. at 520 .

34. Id. at $524-25$.

35. Id. at 525-26. See notes 15-16 supra and accompanying text.

36. Id. at 527 . 
ability to obtain reimbursement of expenses from the licensee; second, allowing reimbursement might encourage opportunists to file frivolous or unsubstantial petitions. ${ }^{37}$ The court found this reasoning unpersuasive, since these abuses had not occurred in Church of Christ and the Commission had given no reason why the potential for abuse of voluntary reimbursement in the petition to deny situation was any greater than in any other reimbursement situation. ${ }^{38}$ Furthermore, the FCC had found obvious benefits to the public interest in allowing withdrawal of petitioners to deny in certain situations. The Commission had written, as paraphrased by the court, that:

"[T]he settlement of the issues between the station and the petitioning group is generally a desirable goal" because it promotes an atmosphere of "generous cooperation-not strife and suspicion" and "should prove to be more effective in improving local service than would be the imposition of strict guidelines by the Commission." 39

The court also found that by allowing reimbursement of withdrawing petitioners, public participation in decisions which involve the public interest would be encouraged. ${ }^{40}$ In remanding to the agency, ${ }^{41}$ the court adınonished the Commission that public participation is viewed increasingly as "not only valuable, but indispensable."42

In order to assess the reasoning and impact of this decision, it is necessary to examine the evolving triangular relationship between the FCC, the licensee, and the petitioners to deny. Unlike a judicial proceeding where an impartial court decides which of two diannetrically opposed parties will prevail, this triangular relationship presents a community of interest with each party seeking different but not incompatible goals: the licensee seeks to have his license renewed so that he can continue broadcasting and making profits; the petitioners desire a change in the licensee's broadcasting policies and/or operation; and the FCC wants a broadcasting service that will best serve the public interest. However, unlike a judicial proceeding

37. Id. at 522 .

38. Id. at 527 .

39. Id. at 526-27.

40. Id. at 527-28.

41. The case was remanded for the FCC to determine if the expenses sought by the Office of Communication were legitimate and prudent under the standard of section $311(\mathrm{c})$. On remand, the Commission found the expenses were legitimate and prudent and approved the entire sum $(\$ 15,000)$ requested by the Office. The Commission, however, limited its decision to the facts present in the instant case. KCMC, Inc., 35 F.C.C.2d 240, 242, 24 P \& F RAdio Reg. 2D 575, 577 (1972).

42. 465 F.2d at 527. 
where the two parties often can compromise and conclusively settle their dispute without obtaining court approval, the petitioners and the licensee still must convince the interested third party, the Commission, that the granting of a renewal license pursuant to the prior agreement will serve the public interest. ${ }^{43}$

The Church of Christ court was convinced that the role of the Commission would effectively insure that any agreement reached would advance the public interest. Once this paramount interest was assured, the court concluded that a voluntary agreement of reimbursement presented no greater danger of abuse between petitioner and licensee than similar agreements which the Commission occasionally allows in challenger-licensee situations. ${ }^{44}$ An analysis of the dual abuses, which the FCC believed would stem from allowing voluntary reimbursement, readily illustrates the correctness of the court's contention.

The first potential danger is that the settlement terms might be influenced by the ability to obtain a voluntary agreement for reimbursement. ${ }^{45}$ It is widely recognized that inadequate financial resources is a matter of major practical concern to local groups considering the filing of a petition to deny. ${ }^{48}$ The court's reasoning-allowing voluntary reimbursement will encourage greater public participation in the license renewal process ${ }^{47}$-is an implicit admission that local groups will be somewhat reluctant to engage in the process if they would thereby incur non-reimbursable expense. However, once such groups enter into the process, the possibility undeniably exists that they might bargain away some objectives in return for a voluntary agreement to reimburse. Nevertheless, as analogous reimbursement cases involving challengers or competitors demonstrate, the Commission has been willing to inquire into the merits of any settlement, ${ }^{48}$ and the mere possibility of coercive compromise need not and has not deterred the Commission from approving

43. For a discussion of the merits of this triangular model of citizen participation in the license renewal process, see Note, The Texarkana Agreement as a Model Strategy for Citizen Participation in FCC License Renewals, 7 HARv. J. LEGIS. 627 (1970).

44. See, e.g., Capital Broadcasting Corp., 3 F.C.C.2d 285, 7 P \& F RAdro REo. 2D 226 (Rev. Bd. 1966). See notes 29-30 supra and accompanying text.

45. 465 F.2d at 522 .

46. See Note, supra note 43 , at 634 .

47. 465 F.2d at 527-28. See note 40 supra and accompanying text.

48. See cases cited in note 25 supra. 
settlements after inquiry has revealed that the public interest would be served. ${ }^{49}$

The Commission's conduct in non-petitioner situations underscores the anomalous character of its decision to erect an absolute bar against reimbursement of petitioners. Lacking the resources to conduct im-depth investigations into the particular needs of each community, the FCC by necessity has left this task to local groups. ${ }^{50}$ The Commission has indicated that it desires

licensees to meet with community oriented groups to settle complaints of local broadcast service. Such cooperation at the community level should prove to be more effective in improving local service than would be the imposition of strict guidelines by the Commission. ${ }^{51}$

Despite the Commission's objections, this policy of encouragement will be facilitated by the court's holding that "legitimate and prudent" expenses of local groups may be assumed voluntarily by the licensee. The local groups will not only be more willing to enter imto the relicensing process, but they can also provide an additional benefit which is only hinted at by the Commission's statement: the continuous monitoring of a relicensee to insure compliance with the settlement. ${ }^{52}$ Thus, allowing voluntary reimbursement will strengthen the triangular relationship in the relicensing process by encouraging entry of the public and providing a greater probability of increased and continuous scrutiny of the relicensee's performance..$^{53}$

The second serious abuse feared by the Commission was the filing of insubstantial or frivolous petitions to deny. ${ }^{54}$ As the court poimted out, however, this possibility exists to some degree in all relicensing controversies. ${ }^{55}$ To mitigate this problem in the petitioner situation, it becomes essential that the licensee be able to assess ac-

49. See cases cited in note 25 supra. The Commission's mandate to further the public interest would be violated only if a specific agreement was not in the public interest. The mere possibility that a settlement was reached through a coercive compromise on substantive issues is not, of and in itself, against the public interest.

50. See Note, supra note 43 , at 638 .

51. KCMC, Inc., 19 F.C.C.2d 109, 16 P \& F RAD1o REG. 2D 1067, 1068 (1969).

52. The "cooperation" which the Commission sought, see text accompanying note 51 supra, would "prove more effective in improving local service" if predicated on the realization that the licensee's day-to-day performance was being utilized as a measuring stick, instead of viewing his cumulative performance at the end of the license period. See note 60 infra.

53. See note 50 supra, and accompanying text.

54. 465 F.2d at 522 .

55. Id. at 525 . 
curately the substantiality of the charges leveled in the petition. With the threat of relicensing denial ever present, a licensee is likely to negotiate any issues which tend to appear substantial and, further, to offer reimbursement as an added incentive for settlement. To clarify the bargaining position of the licensee, the Commission nust outline with reasonable precision which issues will be deeined substantial and present a real threat to license renewal. Because of the complexity of this area, clarification of some issues may realistically only be attainable through adjudication. However, within certain broad categories, the FCC has defined characteristics and standards to which competing applicants for an imitial license inust conform; ${ }^{56}$ there is no reason to beheve that the Commission is incapable of clarifying the renewal area as well. Even though absolute clarification may never be obtained, the licensee can be aided sufficiently to enable him to avoid engaging in needless bargaining over insubstantial issues. ${ }^{57}$

Beyond the resolution of the specific voluntary reimbursement issue, ${ }^{58}$ Church of Christ significantly demonstrates the existence of

56. In Policy Statement on Comparative Broadcast Hearings, 1 F.C.C.2d 393, 5 P \& F RADIO REG. 2D 1901 (1965), the Commission attempted to state the factors to consider when choosing between competing applicants for an initial broadcast license. The Commission said:

The hearing and decision process is inherently complex, and the subject does not lend itself to precise categorization .... The various factors cannot be assigned absolute values, some factors may be present in some cases and not in others, and the differences between applicants with respect to each factor are almost infinitely variable.

Furthermore, membership on the Commission is not static and the views of individual Commissioners on the importance of particular factors may change. ...

All this being so, it is nonetheless important to have a high degree of consistency of decision and of clarity in our basic policies. . . .

This statement is issued to serve the purpose of clarity and consistency of decision . . . We recognize, of course, that a general statement cannot dispose of all problems or decide cases in advance. ... Difficult cases will remain difficult. Id. at 393-94.

However, the Commission listed factors such as diversification of control of the media, proposed program service, character, in the order of weight to be given each. While, of course, borderlime and yet substantial questions will remain in any complex area, the same clarification of what will be considered a substantial issue in the petition-to-deny situation should be attainable after adjudication of diverse factual situations.

57. The promulgation of clarified standards would enable monitoring local groups to identify substantial failings in the performance of the licensee more easily.

58. An issue not reacled by the Church of Christ court was whether a relicensee could be ordered to reimburse a petitioner, in the absence of an agreement to do so, after a settlement had been agreed upon by the parties and approved by the FCC. See 465 F.2d at $528 \&$ n.38. The Commission, subsequent to its Church of Christ decision but prior to the court's reversal, had declined to order involuntary reim- 
a continuing, fundamental disagreement between the D.C. Circuit and the FCC. On the one hand, the Commission has chosen to increase the "stability" of the broadcast industry by limiting, at the license renewal stage, the circumstances under which a licensee's application for relicensing can effectively be challenged, ${ }^{59}$ whether by competitors $^{60}$ or petitioners to deny. ${ }^{61}$ On the other hand, the courts

bursement. Radio Station WSNT, Inc., 31 F.C.C.2d 1080, 23 P \& F RADIo REG. 2D 53 (1971). See note 30 supra.

It seems clear that the salutary effects the court found in the increased availability of reimbursement would in no way be diminished by a lack of voluntariness. In fact, eliminating the hurdle of obtaining a voluntary agreement would substantially reduce any possibility of coercive settlements, further stimulate the desire of local groups to enter the relicensing process, and probably have the beneficial effect of speeding negotiation and settlement in order to minimize expenses. The only detriment likely to arise from dropping the voluntarisess requirement would be the increased possibility of insubstantial or frivolous petitions; however, the suggested promulgation of clarified guidelines for the determination of the substantiality of issues would mitigate the deleterious effect of such petitions. See text accoinpanying note 56 supra. Therefore, when the Commission next faces this problem, see note 18 supra, or the issue is raised on review before the courts, the proper resolution should be an absolute requirement of reimbursement when a relicense is granted pursuant to an agreement settling substantial issues raised by petitioners to deny.

59. The Comunission summarized its position as follows:

Promotion of [the public interest standard], with respect to competing challenges to renewal applicants, calls for the balancing of two obvious considerations. The first is that the public receive the benefits of the statutory spur inherent in the fact that there can be a challenge, and indeed, where the public interest so requires, that the new applicant be preferred. The second is that the comparative hearing policy in this area must not undermine predictability and stability of broadcast operation. Policy Statement on Comparative Hearings Involving Regular Renewal Applicants, supra note 27, at 424-25.

The Commission saw two basic reasons for requiring stability in the broadcast industry: (1) there is a large investment involved in establishing and operating a station; and (2) if the relicensing is frequently denied, opportunistic entrepreneurs may seek licenses with the intention of maximizing short-tern profits, by giving poor service at a minimum investment, with the expectation that the license will not be renewed. Id.

60. Citizens Communications Center v. FCC, 447 F.2d 1201 (D.C. Cir. 1971), noted in 1971 Duke Project 182, concerned a 1970 FCC policy statement, Policy Statement Concerning Comparative Hearings Involving Regular Renewal Applicants, supra note 27 , which established license renewal procedures extremely favorable to renewal applicants. Under the FCC guidelines, if the licensee could show that his performance had substantially met the needs and interests of his broadcasting area, his license would be renewed irrespective of the qualifications of competing applicants. According to the District of Columbia Circuit Court of Appeals, this pohicy virtually immunized the licensee from competition:

Even more important perhaps is the deadening effect the Policy Statement

has had since its institution upon renewal challengers generally. ...

[T] served to deter the filing of a single competing application for a television renewal in over a year ....447 F.2d at 1206 .

The court, in holding that this policy violated the Congressional mandate to the 
have repeatedly rejected this position and instead have substituted guidelines which would encourage public and competitor participation in the license renewal process. ${ }^{62}$ Recognizing that both the judiciary and the agency profess to be striving for the same goal-furtherance of the public interest ${ }^{63}$ - the question of whether the public interest will be better served by increasing stability or by increasing public participation at the agency level is one that perhaps cannot be answered in the piecemeal fashion necessitated by judicial review of individual agency decisions. This fundamental difference of approach could more properly be settled by legislative clarification of the public's role im the relicensing process.

FCC, attempted to reduce the "operational bias in favor of incumbent licensees." Id. at 1207.

61. In Office of Communication of the United Church of Christ v. FCC, 359 F.2d 994 (D.C. Cir. 1966), the questions presented to the court were: whether listeners or viewers of a station should be granted standing as "parties in interest" to contest the renewal of a broadcast station license. In the event the listeners had standing, the Commission was required to conduct an evidentiary hearing on their claims prior to acting on renewal of the license. Id. at 997. The Court of Appeals for the District of Columbia Circuit reversed the Commission's denial of standing to public petitioners and remanded for a full evidentiary hearing. Id. at 1005. Thus the court opted for increased public participation in relicensing challenges.

Office of Communication of the United Church of Christ v. FCC, 425 F.2d 543 (D.C. Cir. 1969), presented the issue of whether the Commission was correct in determining that aggrieved listening or viewing groups must carry "the entire burden of showing that the licensee was not qualified to be granted a renewal." Id. at 549. The court severely criticized the Commission's attitude toward the local groups and the treatment of their complaints:

We did not intend that intervenors representing a public interest be treated as interlopers. Rather, if analogues can be useful, a "Public Intervenor" who is seeking no license or private right is, in this context, more nearly like a complaining witness who presents evidence to police or a prosecutor [the Commission] whose duty it is to conduct an affirmative and objective investigation ....IId. at 546 .

The court in Church II went on to place the burden of proof squarely upon the licensee. Id. at 550; see 83 HARV. L. REv. 1412 (1970). By doing so, the court incrcased the siguificance of a consumer's petition to deny in the license renewal process.

62. See 465 F.2d 519, 528; 425 F.2d 543, 549-50; 359 F.2d 994, 1005.

63. Compare, e.g., Office of Communication of the United Church of Christ v. FCC, 465 F.2d 519, 528 (D.C. Cir. 1972) with KCMC, Inc., 25 F.C.C.2d 603, 604-05; Citizens Communications Center v. FCC, 447 F.2d 1201, (D.C. Cir. 1971) 1214 with Policy Statement Concerning Comparative Hearing Involving Regular Renewal Applicants, 22 F.C.C.2d 424, 424-25 (1970). 